\title{
DODONAEA (SAPINDACEAE): TAXONOMIC NOTES
}

\author{
D.J. McGillivray \\ (Received July 1973)
}

\section{ABSTRACT}

McGillivray, D.J. (National Herbarium of New South Wales, Royal Botanic Gardens, Sydney, Australia) 1975. Dodonaea (Sapindaceae): Taxonomic Notes. Telopea 1 (1): 66-67. -Dodonaea serratifolia sp. nov., New South Wales, and D. coriacea (Ewart et Davies) stat. nov., Northern Territory and Western Australia, are published here. D. polyandra Merrill et Perry ( $D$. viscosa var, laurina J. Britten, synon. nov.) from New Guinea, is recorded for Australia.

Dodonaea serratifolia $D$. McGillivray, sp. nov. differt.

D. lanceolatae F. Muell. affinis, sed foliis serratis et calyce foemineo deciduo

Holotype: NeW South Wales: Grassy Creek, Gibraltar Range National Park, R. Paine NSW 121560, 13.xii.1966. (Located in the National Herbarium of New South Wales.)

Glabrous polygamous shrub c. $1.5 \mathrm{~m}$ high, branchlets semiterete to trigonous: Leaves narrowly elliptical tending to narrowly ovate, $4-8 \mathrm{~cm} l o n g, 0.5-1.5 \mathrm{~cm}$ wide, sparingly resinous with a dull even surface; leaf margin irregularly serrulate; venation obscure except for mid-vein. Inflorescences terminal on short axillary branches, consisting of few- to several-flowered racemes or short panicles; peduncles and pedicels resinous. Bisexual flowers (? male in function): calyx narrowly ovate to ovate, acute, $2.0-2.5 \mathrm{~mm}$ long, resinous, margins ciliate; stamens 4-7; filaments $0.5-1.5 \mathrm{~mm}$ long, anthers oblong, apiculate, $2.2-2.8 \mathrm{~mm}$ long, $0.8-1.0 \mathrm{~mm}$ wide; ovary trigonous, elliptical in outline c. $1 \mathrm{~mm}$ long at anthesis, style 1-5 mm long at anthesis. Female flowers: not observed at anthesis, calyx caducous. Fruits peripterous, 13-18 mm long; seed wings widest towards upper margin, maximum width c. $4 \mathrm{~mm}$; fruits (minus wings) elliptical in outline 10-13 mm long, 7-8 $\mathrm{mm}$ wide; seeds 2 per loculus, dark brown, shiny, broadly ovate, $2 \mathrm{~mm}$ long, $1.2 \mathrm{~mm}$ thick, the margin surrounded for $\frac{3}{4}$ of its length by a clear, fine, wrinkled membrane $0.5-0.7 \mathrm{~mm}$ wide.

Distribution: Eastern side of the Northern Tablelands of New South Wales, on granitic soils in moist situations.

Specimens Examined: Northern Tablelands: Henry River, near Mt. Slow (SE. of Glen Innes), $J B$. Williams NSW 121586, 21.10.1966: Gibraltar State Forest, 38 miles $(61 \mathrm{~km})$ east of Glen Innes, J.B. Williams 646, 5.10 .1958 (NSW).

Dodonaea coriacea (Ewart et Davies) D. McGillivray, stat. nov.

BAsIONYm: Dodonaea peduncularis var. coriacea Ewart et Davies, Fl. N. Territory: 175 (1917).

Holotype: Northern Territory, 70 miles N. of Camp IV, (c. $21^{\circ} \mathrm{S}, 132^{\circ} 30^{\prime} \mathrm{E}$ ) G.F. Hill 390, 28.vi.1911 (MEL).

Dodonaea coriacea is a shrub $0.6-1.5 \mathrm{~m}$ high, characterized by resinous, light orange branchlets; cuneate leaves $10-25 \mathrm{~mm}$ long, $3-8 \mathrm{~mm}$ wide with truncate apex and uneven to irregularly serrate margins; persistent calyx; fruits 
commonly straw-coloured, overall size $12-16 \mathrm{~mm}$ long, $15-20 \mathrm{~mm}$ wide with wings 4-6 $\mathrm{mm}$ wide (at centre).

It is distinguished from $D$. peduncularis Lindl. by its resinous light orange branchlets, broader truncate leaves and larger fruits with wider wings.

SELECTED SPECIMENS, in the National Herbarium of New South Wales (east to west): Northern TERRITORY: Wonarah, Swinboume $764,29.3 .1963 ; 27$ miles [43 $\mathrm{km}] \mathrm{S}$. of Tennant Ck, Forde 228, 4.7.1956; 17 miles [27 km] N. of Helen Springs Station, Perry 1899, $15.8 .1948 ; 24$ miles $[38 \mathrm{~km}]$ SE. of Willowra H.S., Chippendale $N T 4827,1.8 .1958 ; 43.6$ miles $[69 \mathrm{~km}] \mathrm{E}$. of The Granites, Chippendale $N T$ 4280, 4.5.1958. Western AUstralia: Bohemia Downs, c. $105 \mathrm{~km}$ SE. of Fitzroy Crossing, Beard 4251, 28.5.1965; 87 miles [140 km] from Wittenoom towards Millstream Station, Gittins 1485, 8.1967.

Dodonaea polyandra Merrill et Perry in J. Arnold Arbor. 21: 525 (1940), here recorded for Australia.

D. viscosa var. laurina J. Britten in Banks \& Solander, I11. Bot. Cook's Voy, 1: 16, t. 42 (1900), synon. nov. $(\mathrm{BM})$.

Lectotype: Queensland: Lookout Point ('Cape Grafton'), Banks \& Solander, 1770

SYNTYPE: Cunningham 147 (K).

In the register of specimens made during the progress of Cook's first voyage, Solander recorded specimens of this species only from "Cape Fear", a locality named by Cook as Point Lookout (now known as Lookout Point), and Parkinson annotated his original sketch of the plant 'P.F.' (Point Fear).

Dodonaea polyandra has been confused with $D$. viscosa (L.) Jacq. both in Australian and New Guinean collections. It differs from the latter species in its sparsely-veined smooth leaves with smooth margins, more slender anthers, and narrower carpels in fruit. It is more closely related to $D$. triquetra Wendl. from which it is distinguished by its consistently broader, elliptical to obovate leaves and larger fruits.

More recent gatherings of this species in Australia are represented by material in the Queensland Herbarium (BRI) and in the collections of the late Dr L.J. Brass (Nos. 18410, 18773, 18833, 19085, 19244, 19564, 19669). 